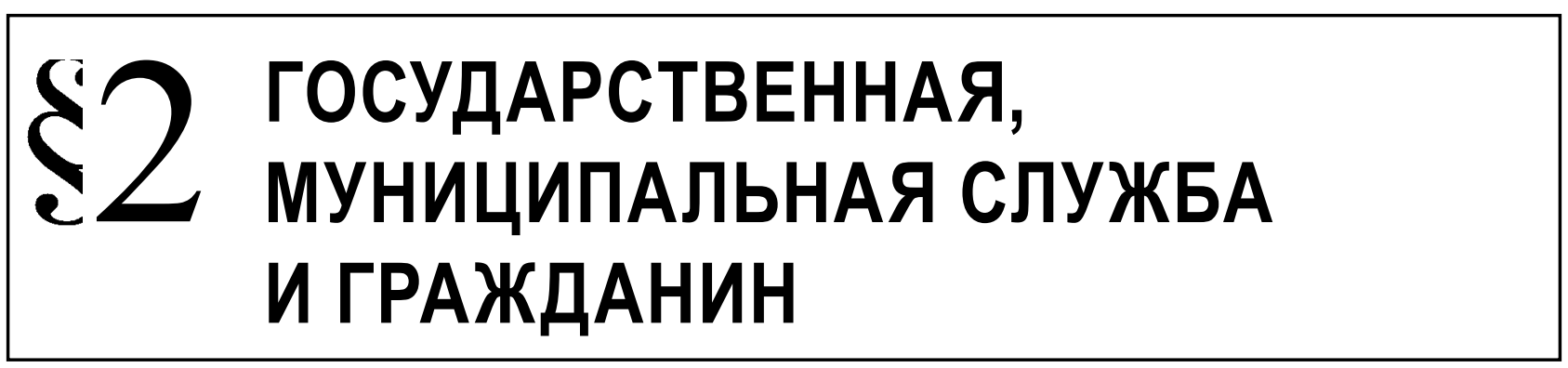

Занко Т.А.

\title{
ОСОБЕННОСТИ ПРОХОЖДЕНИЯ ФЕДЕРАЛЬНОЙ ГОСУДАРСТВЕННОЙ ГРАЖДАНСКОЙ СЛУЖБЫ В ТОРГОВЫХ ПРЕДСТАВИТЕЛЬСТВАХ РОССИЙСКОЙ ФЕДЕРАЦИИ
}

\begin{abstract}
Аннотация. Аннотация: В качестве предмета исследования выступают нормы права, регулирующие процесс прохождения федеральной государственной гражданской службы в загранаппарате Министерства экономического развития Российской Федерации. В статье дана краткая характеристика основных этапов становления системы торговых представительств, изучен современный механизм управления внешнеэкономической деятельностью, проанализированы условия и порядок поступления на государственную гражданскую службу в систему торговых представительств, квалирикационные требования к знаниям и навыкам, особенности служебного распорядка, оплаты труда, а также прохождения аттестации и сдачи квалификационного экзамена. При проведении исследования использовались исторический, формально-юридический, структурный и функциональный методы, которые обеспечили комплексное изучение проблематики прохождения федеральной государственной гражданской службы в торговых представительствах. В результате анализа выявлены особенности правового регулирования прохождения федеральной государственной гражданской службы в загранаппарате Минэкономразвития, в частности особенности отбора, требования к знанию иностранных языков, денежного содержания в рублях и в иностранной валюте, условия предоставления отпуска, а также предоставления дополнительных государственных гарантий.

Ключевые слова: государственная служба, государственная гражданская служба, дипломатическая служба, торговые представительства, Минэкономразвития России, государственные гарантии, Правительство, Министерство иностранных дел, исполнительная власть, Президент.

Review. The study analyzes legal rules regulating federal civil service in trade missions of the Ministry of economic development of the Russian Federation. The article summarizes the stages of formation of trade missions, analyzes the modern system of foreign economic activity management, as well as the conditions and procedures of admission to the civil service in trade missions, qualification requirements for knowledge and skills, the peculiarities of service schedule, remuneration of labor and the procedure of certification and qualification examination. The study uses the historical, legal, structural and functional methods which provide a comprehensive study of aspects of federal civil service in trade missions. The analysis reveals the features of legal regulation of federal civil service in trade missions of the Ministry of economic development, in particular, special aspects of competitive selection, requirements for knowledge of foreign languages, supply in rubles and in foreign currency, procedure of vacation granting, as well as provision of additional state guarantees.

Keywords: state guarantees, Ministry of economic development, trade missions, foreign service, civil service, public service, Government, Ministry of foreign affairs, executive authority, President.
\end{abstract}

$\mathrm{T}$ орговые представительства являются важнейшим элементом в механизме проведения внешнеторговой политики Российской Федерации и приобретают особое значение в период международного финансово-экономического кризиса, а также в условиях зарубежной санкционной политики. Помимо указанных обстоятельств отмечается всё возрастающий уровень межгосударственной конкуренции, её более агрессивный и разнообразный характер, который требует, в свою очередь, системных усилий от Российской Федерации по укреплению национальной конкуренто- 
способности, с целью обеспечению национальных интересов в быстро меняющейся глобальной экономической и торгово-политической ситуации [1].

История отстаивания внешнеторговых интересов берёт своё начало ещё со времен учреждения в 1549 году Иваном Грозным Посольского приказа, получает своё развитие с созданием Петром I в 1717 году Коммерц-коллегии. В дальнейшем государственным управлением в рассматриваемой сфере занимались Министерство коммерции с 1802 года, а с 1905 года - Министерство промышленности и торговли, причём важным этапом было учреждение в 1912 году заграничного аппарата указанного министерства. В 1918 году внешняя торговля была национализирована [2], и в целом в советское время внешнеторговые вопросы находились в ведении сначала Наркомата внешней торговли (с 1920 г.), а в дальнейшем Министерства внешней торговли (с 1946 г.) [3].

К основным звеньям современного аппарата государственного управления внешней торговлей на федеральном уровне можно отнести Президента Российской Федерации, профильные комитеты палат Федерального Собрания Российской Федерации, Правительство Российской Федерации, Министерство экономического развития Российской Федерации, Министерство иностранных дел Российской Федерации, государственную корпорацию Внешэкономбанк.

Президент Российской Федерации определяет основные направления внешней политики, включая приоритеты внешнеэкономической политики, а также подписывает международные договоры, многие из которых носят как раз внешнеторговый характер. Президент представляет Российскую Федерацию в международных отношениях, в том числе в рамках крупных региональных экономико-политических объединений, союзов и форумов (например, ЕАЭС, БРИКС, АТЭС, АСЕАН, ШОС) [4]. Реализация полномочий главы государства в сфере внешнеэкономической деятельность обеспечивается в комплексе целым рядом подразделений Администрации Президента, среди которых можно выделить Управление по внешней политике, Контрольное управление, Экспертное управление, Управление по социально-экономическому сотрудничеству с государствами-участниками СНГ, Республикой Абхазия и Республикой Южная Осетия. При Президенте Российской Федерации действует Комиссия по мониторингу достижения целевых показателей социально-экономического развития России, а также Совет по модернизации экономики и инновационному развитию России и Экономический совет.

Профильным комитетом Совета Федерации выступает Комитет по экономической политике, в спектр задач которого входят вопросы внешнеэкономической деятельности, а также стимулирование экономической деятельности хозяйствующих субъектов методами таможенного регулирования, вопросы деятельности ВТО. В Государственной Думе схожей проблематикой занимается Комитет по экономической политике, инновационному развитию и предпринимательству.

Полномочия высшего коллегиального органа исполнительной власти в области внешнеэкономической деятельности сосредоточены в ст. 14 Федерального конституционного закона от 17 декабря 1997 г. № 2-ФКЗ «О Правительстве Российской Федерации» и заключаются в разработке и реализации государственной политики в сфере международного экономического, финансового, инвестиционного сотрудничества, общем руководстве таможенным делом, принятии мер по защите интересов отечественных производителей товаров, работ, услуг. Среди ключевых нормативных правовых актов, определяющих содержание деятельности Правительства, можно назвать «Основные направления деятельности Правительства Российской Федерации на период до 2018 года» [5], п.3 раздела II которых посвящён продвижению бизнеса на новые рынки и среди прочего предусматривает меры по формированию максимально удобной экспортной инфраструктуры, устранению излишних процедурных обременений, повышению эффективности нефинансовых институтов поддержки экспорта. В рамках реализации указанных основных направлений было принято распоряжение Правительства Российской Федерации от 3 апреля 2015 г. № 593-р, которым была утверждена новая редакция «дорожной карты» «Поддержка доступа на рынки зарубежных стран и поддержка экспорта», которая также подкрепляется «Планом первоочередных мероприятий по обеспечению устойчивого развития экономики и социальной стабильности в 2015 году», утверждённым распоряжением Правительства Российской Федерации от 27 января 2015 года № 98-р. $\mathrm{C}$ точки зрения распределения обязанностей курирование вопросов внешнеэкономической деятельности возложено на Первого заместителя Председателя Правительства (И.И. Шувалова).

Министерство иностранных дел Российской Федерации, во-первых, выполняет важнейшую координирующую функцию [6] в проведении единой 
внешнеполитической линии, во-вторых, как раз через систему загранучреждений МИД России обеспечивается реализация в том числе и внешнеэкономического курса страны [7].

Государственная корпорация Внешэкономбанк призвана осуществлять финансовую и гарантийную поддержку российского экспорта. С этой целью Внешэкономбанк предоставляет экспортные кредиты иностранным покупателям, с одной стороны, а также финансирует деятельность российских экспортёров, покрывая расходы на производство продукции для последующей поставки иностранным покупателям, с другой стороны. Внешэкономбанк осуществляет гарантийную поддержку экспорта путём предоставления гарантий надлежащего исполнения, платежа, возврата аванса, других видов гарантий, а также осуществляет поддержку российских прямых инвестиций за рубежом [8]. Наряду с Внешэкономбанком в данном процессе участвуют АО «Российский экспортный центр», ОАО «Российское агентство по страхованию экспортных кредитов и инвестиций», а также $3 А О$ «Государственный специализированный Российский экспортно-импортный банк» [9].

Правовые основы внешнеторговой деятельности определены Федеральным законом от 8 декабря 2003 года № 164-Ф3 «Об основах государственного регулирования внешнеторговой деятельности», который прежде всего исходит из принципов защиты прав и законных интересов участников внешнеторговой деятельности, их равенства и недискриминации, взаимности, гласности, обоснованности и объективности применения мер государственного регулирования, исключении неоправданного вмешательства государства, единства системы государственного регулирования ВЭД и др [10].

Ключевым звеном в реализации внешнеторговой политики выступает Министерство экономического развития Российской Федерации [11], деятельность которого направлена на комплексное применение всего спектра внешнеэкономических инструментов и во многом ориентирована на реализацию Внешнеэкономической стратегии до 2020 года - документа, в котором зафиксированы отраслевые и географические приоритеты внешнеторговой политики России.

В структуре Минэкономразвития России действует ряд функциональных и территориальных департаментов, обеспечивающих реализацию полномочий в сфере внешнеэкономической деятельности. Среди функциональных департаментов можно выделить Департамент координации, раз- вития и регулирования внешнеэкономической деятельности, Департамент торговых переговоров, Департамент тарифного регулирования и анализа внешнеэкономической деятельности; к территориальным департаментам относятся Департамент Азии, Африки и Латинской Америки, Департамент стран Европы, Северной Америки и международных организаций, Департамент взаимодействия с органами Таможенного союза и экономического сотрудничества со странами СНГ. Руководство деятельностью указанных подразделений возложено на Первого заместителя Министра экономического развития (А.Е. Лихачёва), что свидетельствует об особом значении, которое придаётся вопросам внешнеэкономического сотрудничества.

Загранаппарат Минэкономразвития России составляют торговые представительства, Постпредство при ВТО [12], а также специалисты в постоянных представительствах при международных организациях.

Торговые представительства - важнейшие инструменты экономической дипломатии [13], которые учреждаются на основании договора между Российской Федерацией и иностранным государством. При этом важным аспектом выступает то обстоятельство, что торговое представительство является составной частью дипломатического представительства Российской Федерации в государстве пребывания и осуществляет свою деятельность под непосредственным политическим руководством Посла Российской Федерации в этом государстве [14]. При этом, с учётом принятия Федерального закона от 27 июля 2010 г. № 205Ф3 «Об особенностях прохождения федеральной государственной гражданской службы в системе Министерства иностранных дел Российской Федерации», правовой статус дипломатических работников и государственных гражданских служащих торгового представительства стал принципиально отличаться, несмотря на то, что между указанными подвидами государственной гражданской службы скорее больше общих черт, чем отличий.

На 2015 г. Российской Федерацией учреждены торговые представительства в 55 странах, которые решают задачи по расширению и диверсификации российского экспорта товаров и услуг, созданию условий для реализации конкурентных преимуществ России, анализу и прогнозированию состояния внешнеэкономических отношений с государством пребывания, выработке и реализации мер по реализации благоприятных условий интеграции экономии России в мировую экономику, обеспечению позиции Рос- 
сии в международных экономических организациях, а также иные направления комплексной поддержки участников внешнеторговой деятельности. Если рассматривать географическое расположение торговых представительств, то наибольшее их количество учреждено в Европе - 24; в Азии учреждено - 19; Африке - 3; Северной Америке - 2; Южной Америке - 2; Центральной Америке - 1; Австралии - 1.

Прохождение государственной службы в торговых представительствах основывается на нормах Федерального закона «0 государственной гражданской службе» от 27 июля 2004 года № 79Ф3 с учётом особенностей, рассмотренных далее. Процесс прохождения государственной гражданской службы в системе торговых представительств обеспечивается Департаментом кадров и организационного развития Минэкономразвития России.

\section{Должностная структура торговых представительств}

Группы и категории должностей загранаппарата Минэкономразвития России установлены отдельным разделом (10) «Перечня должностей в представительствах Российской Федерации, представительствах федеральных органов исполнительной власти за рубежом» Реестра должностей федеральной государственной гражданской службы [15]. Среди должностей категории «руководители» можно выделить должность торгового представителя (высшая группа); представителя (постоянный представитель) при международной организации (главная группа); заместителя торгового представителя, заместителя представителя при международной организации, начальника и заместителя начальника отдела представительства (ведущая группа). К категории «советники» ведущей группы должностей относятся должности помощника торгового представителя или постоянного представителя при международной организации. Также в загранаппарате учреждаются должности категории «специалисты» - торговый советник, торговый атташе, консультант (ведущая группа), главный специалист-эксперт, ведущий специалист-эксперт, специалист-эксперт (старшая группа); а также должности категории «обеспечивающие специалисты» - старшие специалисты 1 и 2 разряда (старшая группа), специалист 1 разряда (младшая группа).

Примерные должностные регламенты федеральных государственных гражданских служащих загранаппарата утверждены Приказом Минэкономразвития от 7 апреля 2014 г. № 207 и содержат по каждой должности квалификационные требования к уровню и характеру знаний и навыков, образованию, стажу гражданской службы; должностные обязанности, права и ответственность; перечень вопросов, по которым государственный гражданский служащий вправе или обязан самостоятельно принимать управленческие решения либо участвовать в подготовке проектов нормативных правовых актов и (или) проектов управленческих решений, а также сроки, процедуры, порядок согласования указанных актов и решений; порядок служебного взаимодействия; перечень государственных услуг, оказываемых служащим; показатели эффективности и результативности профессиональной служебной деятельности [16].

\section{Отбор на государственную гражданскую службу в торговые представительства}

С учётом того обстоятельства, что прохождение государственной гражданской службы в торговых представительствах предусматривает длительное пребывание служащего за рубежом, требует специальных экономических, правовых и иных знаний, к государственным гражданским служащим, претендующим на работу в системы торговых представительств, предъявляются особые квалификационные требования.

Квалификационные требования (с учётом категорий и групп должностей) к профессиональным знаниям и навыкам, необходимым для исполнения должностных обязанностей государственными гражданскими служащими загранаппарата Минэкономразвития, утверждены Приказом Министерства от 7 июня 2013 г. № 314 [17] и предусматривают, наряду с общими для всех государственных гражданских служащих требованиями, знание направлений и приоритетов внешнеэкономической политики Российской Федерации, иностранного языка, а также владение навыками ведения деловых переговоров и бесед с представителями иностранных государств и международных организаций, публичного выступления перед иностранной аудиторией.

По сути необходимым условием для поступления на государственную службу для работы в системе торговых представительств является наличие высшего профессионального образования в области внешнеэкономических отношений и внешней торговли по специальностям «мировая экономика», «международные экономические отношения», «внешняя торговля», «юриспруденция», а также профессиональное знание иностранных 
языков (арабского, венгерского, голландского, датского, индонезийского, испанского, итальянского, китайского, корейского, малазийского, немецкого, норвежского, персидского, польского, финского, французского, хинди, чешского, шведского, японского), а для работы в торговых представительствах в странах СНГ желательно знание государственных языков этих стран (армянского, азербайджанского, казахского, киргизского, таджикского, туркменского, узбекского). При этом знание английского языка является дополнительным преимуществом, а не основным требованием.

В виду того, что работа в торговых представительствах предполагает длительное нахождение за рубежом, наличие супруга также является положительным фактором при принятии решении о приёме на государственную службу в загранаппарат Минэкономразвития России.

Кандидаты на работу в торговых представительствах в обязательном порядке проходят: медицинское обследование в поликлиниках Министерства (с учётом того, что работа в торгпредствах предусматривает нахождение в странах со сложными природно-климатическими условиями), тестирование уровня владения иностранным языком (данная работа организуется Высшими курсами иностранных языков Минэкономразвития России), стажировку в департаментах по будущему направлению деятельности, а также собеседование в Комиссии по отбору кандидатов для рассмотрения на работу в загранаппарат Минэкономразвития России.

В случае соответствия указанным выше требованиям и прохождения отбора назначение на должность оформляется приказом Минэкономразвития России, на основании которого с государственным гражданским служащим заключается служебный контракт, примерные формы которого установлены Приказом Минэкономразвития от 3 августа 2007 года № 269 [18], при этом примерные формы контрактов систематизированы в зависимости от категорий должностей государственной гражданской службы. Торговые представители Российской Федерации назначаются и освобождаются от должности Правительством Российской Федерации по представлению Минэкономразвития России, согласованному с МИД России.

В соответствии с законодательством о противодействии коррупции при назначении на должности государственной гражданской службы все категории служащих загранаппарата обязаны предоставлять сведения о своих доходах, расходах, об имуществе и обязательствах имуществен- ного характера, а также аналогичные сведения о супруге и несовершеннолетних детях, в случае: осуществления функций должностного лица, предоставления государственных услуг гражданам и организациям, осуществления контрольных мероприятий, подготовки и принятии решений о распределении бюджетных ассигнований, управления государственным имуществом, осуществления государственных закупок, выдаче лицензий и разрешений, хранения и распределения материальнотехнических ресурсов [19].

Также сведения о доходах, расходах, об имуществе и обязательствах имущественного характера торгового представителя Российской Федерации, его заместителя, начальника отдела торгпредства, консультанта, главного специалиста-эксперта и ведущего специалиста-эксперта, а также их супругов и несовершеннолетних детей подлежат размещению на официальном сайте в сети интернет (для торгового представителя - во всех случаях, для остальных перечисленных должностей только в случае, если в полномочия входят вопросы распределения бюджетных ассигнований, субсидий, межбюджетных трансфертов, распределения ограниченных ресурсов; осуществления государственных закупок, выдачи лицензий и разрешений, списания объектов движимого и недвижимого имущества, находящегося в федеральной собственности) [20].

В целях повышения эффективности обработки персональных данных, закрепления процесса формирования, ведения, хранения, передачи личных дел и учета персональных данных государственных гражданских служащих загранаппарата действует соответствующая Инструкция, утверждённая Приказом Минэкономразвития России от 2 сентября 2014 года № 549 и устанавливающая исчерпывающие перечни документов, подлежащих хранению, в том числе перечень дополнительных документов, которые приобщаются к личному делу в случае оформления государственного гражданского служащего в загранаппарат Министерства (представление торгпреда либо департамента; план стажировки; выписка из протокола заседания Комиссии по отбору кандидатов на работу в загранаппарат; медицинские справки и анкеты членов семьи государственного гражданского служащего) [21].

\section{Служебный распорядок}

Служебный распорядок регламентирует режим служебного времени и времени отдыха и принимается в целях укрепления служебной дисциплины, 
рационального использования служебного времени, повышения результативности профессиональной деятельности государственных гражданских служащих. Служебный распорядок загранаппарата Минэкономразвития России утверждён Приказом от 6 июня 2013 года № 306 [22].

Нормальная продолжительность служебного времени в торговых представительствах не может превышать 40 часов в неделю, при этом режим служебного времени в торговых представительствах устанавливается приказом руководителя торгпредства с учётом местных условий, а также с учётом графика работы органов государственной власти и организаций страны пребывания [23]. В торговых представительствах для всех категорий и групп должностей государственной гражданской службы устанавливается ненормированный служебный день.

За ненормированный служебный день служащим торгпредств предоставляется дополнительный оплачиваемый отпуск продолжительностью от 3 до 8 дней в зависимости от должности (помимо основного оплачиваемого отпуска продолжительностью до 30 (35 дней - для торговых представителей) и дополнительного оплачиваемого отпуска за выслугу лет из расчёта один день за каждый год службы, которые в сумме не могут превышать 40 дней (45 для торговых представителей).

Помимо указанных оснований на продолжительность дополнительного оплачиваемого отпуска влияют тяжёлые климатические условия, неблагоприятная экологическая и эпидемиологическая обстановка, военные действия и вооружённые конфликты, нестабильная общественно-политическая обстановка, высокий уровень преступности, которые учитываются в перечне стран, утверждаемом постановлением Правительства Российской Федерации [24], а продолжительность такого дополнительного оплачиваемого отпуска в отношении каждой страны устанавливается приказом МИД России [25] и составляет от 3 до 15 дней.

\section{Вопросы этики и служебного поведения}

Вопросы этики и служебного поведения урегулированы Приказом Минэкономразвития России от 23 июня 2011 года № 292, которым был утверждён соответствующий Кодекс, целью которого является обобщение этических норм и установление правил служебного поведения государственных служащих для достойного выполнения ими своей профессиональной деятельности, а также содействие укреплению авторитета государственных служащих, доверия граждан к государственным органам и обеспечение единых норм поведения государственных служащих [26].

Кодекс содержит универсальные правила поведения государственных гражданских служащих центрального аппарата и торговых представительств, при этом не учитывая особенностей прохождения государственной гражданской службы в загранкомандировке и сложных ситуаций, которые могут возникать в процессе её прохождения (например, при проведении межгосударственных мероприятий, посещении органов государственной власти и организации страны пребывания). В то же время с учётом большого количества протокольных мероприятий, в которых участвуют служащие загранаппарата, в Минэкономразвития России действует Приказ от 15 декабря 2014 г. № 803, регламентирующий организацию работы по сообщению Министром либо служащими о получении подарка, его сдаче, оценке, реализации (выкупе) и зачислении средств от его реализации [27].

\section{Денежное содержание}

Государственному гражданскому служащему, замещающему должности в торговом представительстве [28], устанавливается денежное содержание, которое состоит из:

- должностного оклада [29] (выплачивается служащим загранаппарата в рублях (20\%) и в иностранной валюте);

- оклада за классный чин;

- ежемесячной надбавки за выслугу лет;

- ежемесячной надбавки за особые условия гражданской службы в рублях [30] (150\% - главные должности; 90-120\% - ведущие должности; 60-90 \% - старшие должности; до 60 \% - младшие должности);

- ежемесячной надбавки за особые условия гражданской службы в иностранной валюте [31] (до 20 \% оклада - если условия в стране пребывания сопряжены с ограничениями и запретами, а также режимными ограничениями (по факту от 8 до 13\%), 5 \% - в странах с тяжёлыми климатическими и/или неблагоприятными экологическими условиями, 5-7\% - за использование в практической служебной деятельности иностранных языков на профессиональном уровне (европейские языки, восточный или редкий язык, владение двумя и более иностранными языками), 20 \% - торговому представителю); 
- ежемесячной надбавки за работу со сведениями, составляющими государственную тайну [32] (10\% - за работу со сведениями, имеющими гриф «секретно», 30 \% - «совершенно секретно», 75 \% - «особой важности»);

- единовременной выплаты в рублях при предоставлении ежегодного оплачиваемого отпуска и материальной помощи;

- премии в рублях за выполнение особо важных и сложных заданий [33].

В случае намерения государственного гражданского служащего выполнять в соответствии с ч. 2 ст. 14 № 79-Ф3 иную оплачиваемую работу (педагогическую, научную, творческую) ему необходимо письменно уведомить представителя нанимателя (в зависимости от категории должности и порядка назначения - Президента, Председателя Правительства, Министра экономического развития или его заместителя). Работу по регистрации и учёту таких уведомлений проводит отдел по профилактике коррупционных и иных правонарушений Департамента кадров и организационного развития [34].

Аттестация и квалификационный экзамен

Аттестация проводится в целях определения соответствия гражданского служащего замещаемой должности федеральной государственной гражданской службы на основе оценки его профессиональной служебной деятельности [35], в то время как квалификационный экзамен проводится для решения вопроса о присвоении гражданскому служащему классного чина [36]. Состав комиссии по проведению аттестации и сдаче квалификационного экзамена государственными гражданскими служащими загранаппарата включает в себя Первого заместителя Министра - председатель Комиссии (А.Е. Лихачёв), Директора Департамента кадров и организационного развития - заместитель председателя (К.Э. Котцев), директоров территориальных и ряда функциональных департаментов, независимых экспертов от учебных заведений, занимающихся подготовкой кадров для системы торгпредств (BABТ, МГУ, МГИМО). Особенность проведения аттестации и сдачи квалификационного экзамена государственными гражданскими служащими загранаппарата Минэкономразвития заключается в том, что иногда, с учётом нахождения экзаменуемого в государстве пребывания, а также с целью экономии бюджетных средств, используются средства дистанционной мультимедийной связи, которые позволяют без отрыва от служебной деятельности провести необходимые процедуры.

Таким образом, за последние годы произошёл значительный рывок в правовом обеспечении процесса прохождения федеральной государственной гражданской службы в торговых представительствах Российской Федерации, основные цели которого состояли в усилении правовой и социальной защищённости служащих загранаппарата Минэкономразвития, повышении привлекательности государственной службы и формировании высокопрофессионального кадрового состава, поскольку именно на служащих торговых представительств ложится ответственная задача по реализации внешнеэкономической политики Российской Федерации, которая становится особенно актуальной в условиях зарубежной санкционной политики и острой необходимости диверсификации российского экспорта.

\section{Библиография:}

1. Спартак А.Н. Направления и методы международной конкуренции в начале XXI века: геоэкономические и торгово-политические аспекты / Российский внешнеэкономический вестник. - 2011.-№ 9. - С. 3-15

2. О национализации внешней торговли: Декрет СНК РСФСР от 22.04.1918 г. (документ утратил силу)// Известия ВЦИК. - 1918.-№ 80

3. Иванов А.С. Страницы истории торговых представительств России за рубежом / Российский внешнеэкономический вестник. - 2006.-№ 11. - С. 51-58

4. Лихичёв А.Е. Возможности российской экономической дипломатии по защите национальных интересов на мировом рынке (в рамках региональных объединений и саммитов) / Внешнеэкономический бюллетень.-2005.-№ 5. - С. 36-45.

5. Основные направления деятельности Правительства Российской Федерации на период до 2018 года : утверждены Председателем Правительства Российской Федерации 14 мая 2015 г. [Электронный документ] / Документ официально опубликован не был. Сайт Правительства Российской Федерации. - 2015. - Режим доступа: http:// government.ru/media/files/QTqv2SI5qYEuu2zOHkOAwguydbKD9Ckf.pdf

6. О координирующей роли Министерства иностранных дел Российской Федерации в проведении единой внешнеполитической линии : Указ Президента Российской Федерации от 8 ноября 2011 г. № 1478 // Собрание законодательства Российской Федерации. - 2011.-№ 46 - Ст. 6477

7. Об организации и порядке осуществления федеральными органами исполнительной власти и российскими государственными учреждениями функций, связанных с деятельностью за рубежом: Указ Президента Российской Федерации от 14.06.2007 г. № 582 // Собрание законодательства Российской Федерации. - 1997. - Ст. 2743

8. О банке развития : Федеральный закон от 17.05.2007 г. № 82-ФЗ // Собрание законодательства Российской Федерации. - 2007.-№ 22. - Ст. 2562 
9. Ищенко Е.Г., Алексеев П.В. Совершенствование механизма поддержки экспорта в России / Деньги и кредит. 2015.-№ 6. - С. 36-42

10. Об основах государственного регулирования внешнеторговой деятельности : Федеральный закон от 08.12 .2003 г. № 164-Ф3 // Собрание законодательства Российской Федерации. - 2003.-№ 50. - Ст. 4850

11. О Министерстве экономического развития Российской Федерации : Постановление Правительства Российской Федерации от 05.06.2008 г. № 437 // Собрание законодательства Российской Федерации. - 2008.-№ 24. - Ст. 2867

12. Об обеспечении деятельности Постоянного представительства Российской Федерации при Всемирной торговой организации» (вместе с «Положением о Постоянном представительстве Российской Федерации при Всемирной торговой организации») : Постановление Правительства Российской Федерации от 31.01.2014 г. № 68 // Собрание законодательства Российской Федерации. - 2014.-№ 6. - Ст. 584

13. Шлямин В. Торгпредство - эффективный инструмент экономической дипломатии / Дипломатическая служба. 2014.-№ 1. - С. 18-28

14. Об оптимизации системы торговых представительств Российской Федерации в иностранных государствах: Постановление Правительства Российской Федерации от 27.06.2005 г. № 401 // Собрание законодательства Российской Федерации. - 2005.-№ 27. - Ст. 2761

15. О Реестре должностей Федеральной государственной гражданской службы : Указ Президента Российской Федерации от 31.12.2005 г. № 1574 // Собрание законодательстве Российской Федерации. - 2006. - № 1. - Ст. 118

16. Об утверждении примерных должностных регламентов федеральных государственных гражданских служащих центрального аппарата и загранаппарата Минэкономразвития России : Приказ Минэкономразвития России от 07.04.2014 г. № 207 // Российская газета (специальный выпуск). - 2014.-№ 128/2

17. Об утверждении квалификационных требований к профессиональным знаниям и навыкам, необходимым для исполнения должностных обязанностей федеральными государственными гражданскими служащими центрального аппарата и загранаппарата Министерства экономического развития Российской Федерации : Приказ Минэкономразвития России от 07.06.2013 г. № 314 // Российская газета. - 2013.-№ 175

18. О примерных формах служебного контракта о прохождении государственной гражданской службы Российской Федерации и замещении должности государственной гражданской службы Российской Федерации в Минэкономразвития России: Приказ Минэкономразвития России от 03.08.2007 г. № 269 [Электронный ресурс]// Документ официально опубликован не был. - Система Консультант Плюс. - Режим доступа: http://base.consultant.ru/ cons/cgi/online.cgi?req=doc; base=EXP; $=403562$

19. Об утверждении Перечня должностей федеральной государственной гражданской службы в Министерстве экономического развития Российской Федерации, при назначении на которые граждане и при замещении которых федеральные государственные гражданские служащие обязаны представлять сведения о своих доходах, расходах, об имуществе и обязательствах имущественного характера, а также сведения о доходах, расходах, об имуществе и обязательствах имущественного характера своих супруги (супруга) и несовершеннолетних детей : Приказ Минэкономразвития России от 05.11.2014 г. № 701 // Российская газета - 2014.-№ 290

20. Об утверждении перечней должностей, замещение которых влечет за собой размещение сведений о доходах, расходах, об имуществе и обязательствах имущественного характера федеральных государственных гражданских служащих Министерства экономического развития Российской Федерации и работников организаций, созданных для выполнения задач, поставленных перед Министерством экономического развития Российской Федерации, а также сведений о доходах, расходах, об имуществе и обязательствах имущественного характера своих супруги (супруга) и несовершеннолетних детей на официальном сайте Министерства экономического развития Российской Федерации в информационно-телекоммуникационной сети «Интернет» : Приказ Минэкономразвития России от 07.03.2014 г. № 116 // Российская газета. - 2014.-№ 160

21. Об утверждении Инструкции по формированию, ведению, хранению, передаче личных дел и учету персональных данных государственных гражданских служащих и работников Министерства экономического развития Российской Федерации : Приказ Минэкономразвития России от 02.09.2014 г. № 549 [Электронный ресурс] // Документ официально опубликован не был. - Система Консультант Плюс. - Режим доступа: http://base. consultant.ru/cons/cgi/online.cgi?req=doc;base=LAW;n=168195;dst=0;ts=079F061CCE26E580632A6F3FF165F9C1;r nd $=0.3546640919521451$

22. Об утверждении Служебного распорядка центрального аппарата Министерства экономического развития Российской Федерации, торговых представительств Российской Федерации в иностранных государствах: Приказ Минэкономразвития от 06.06.2013 г. № 306 // Российская газета. - 2013.-№ 199

23. Об утверждении примерного служебного (трудового) распорядка торгового представительства Российской Федерации в иностранном государстве: Приказ Минэкономразвития России от 18 августа 2006 г. № 240 [Электронный ресурс] // Документ официально опубликован не был. - Система Консультант Плюс. - Режим доступа: http://merit.consultant.ru/page.aspx?7783

24. О минимальной продолжительности ежегодных дополнительных оплачиваемых отпусков и об условиях их предоставления работникам представительств Российской Федерации за границей: Постановление Правительства Российской Федерации от 21.04.2010 г. № 258 // Собрание законодательства Российской Федерации. - 2010.№ 17. - Ст. 2102

25. О продолжительности ежегодного дополнительного оплачиваемого отпуска, предоставляемого работникам, работающим в странах, предусмотренных перечнем стран с особыми (в том числе климатическими) условиями, дающими право работникам представительств Российской Федерации за границей на ежегодный дополнитель- 
ный оплачиваемый отпуск, утвержденным постановлением Правительства Российской Федерации от 21 апреля 2010 г. N 258 : Приказ МИД России от 8 августа 2011 г. № 14299 // Российская газета. - 2011.-№ 216

26. Об утверждении Кодекса этики и служебного поведения государственных гражданских служащих центрального аппарата и загранаппарата Министерства экономического развития Российской Федерации: Приказ Минэкономразвития России от 24.06.2011 г. № 292 [Электронный ресурс] // Документ официально опубликован не был. - Система Консультант Плюс. - Режим доступа: http://merit.consultant.ru/page.aspx?40257

27. Об организации в Министерстве экономического развития Российской Федерации работы по сообщению Министром экономического развития Российской Федерации и федеральными государственными гражданскими служащими Министерства экономического развития Российской Федерации о получении подарка в связи с их должностным положением или исполнением ими должностных обязанностей, сдаче и оценке подарка, реализации (выкупе) и зачислении средств, вырученных от его реализации : Приказ Минэкономразвития России от 15.12.2014 г. № 803 [Электронный ресурс] // Документ опубликован не был. - Сайт Консультант Плюс. - Режим доступа: http://base.consultant.ru/cons/cgi/online.cgi?req=doc;base=LAW;n=176860

28. О денежном содержании федеральных государственных гражданских служащих, замещающих должности федеральной государственной гражданской службы в федеральном государственном органе, находящемся за пределами территории Российской Федерации: Указ Президента Российской Федерации от 25.07.2006 г. № 764 // Собрание законодательства Российской Федерации. - 2006.-№ 31 (ч.1). - Ст. 3460

29. О повышении окладов месячного денежного содержания/должностных окладов сотрудников загранаппарата Минэкономразвития России: Приказ Минэкономразвития России от 30.11.2007 г. № 420 [Электронный ресурс] // Документ официально опубликован не был. - Сайт Консультант Плюс. - Режим доступа:

30. О размерах и порядке выплаты ежемесячных надбавок к должностному окладу в рублях за особые условия гражданской службы федеральным государственным гражданским служащим загранаппарата Минэкономразвития России: Приказ Минэкономразвития России от 09.04.2007 г. № 121 // Российская газета. - 2007.-№ 98

31. Об утверждении Положения о размерах, условиях и порядке выплаты ежемесячной надбавки к месячному должностному окладу в иностранной валюте за особые условия работы в стране пребывания работникам загранаппарата Минэкономразвития России: Приказ Минэкономразвития России от 28.07.2009 г. № 296 // Российская газета. - 2009.-№ 194

32. О порядке и условиях выплаты ежемесячных процентных надбавок к должностному окладу (тарифной ставке) работникам центрального аппарата и загранаппарата Министерства экономического развития Российской Федерации, подведомственных организаций, допущенным к государственной тайне на постоянной основе, и сотрудникам структурных подразделений по защите государственной тайны: Приказ Минэкономразвития России от 30.12.2007 г. № 467 // Российская газета. - 2008.-№ 39

33. Об утверждении Положения о премировании и выплате материальной помощи работникам загранаппарата Министерства экономического развития Российской Федерации: Приказ Минэкономразвития России от 25.08.2009 г. № 343 // Российская газета. - 2009.-№ 194

34. об организации работы по уведомлению федеральными государственными гражданскими служащими Минэкономразвития России представителя нанимателя о намерении выполнять иную оплачиваемую работу (о выполнении иной оплачиваемой работы) и по регистрации этих уведомлений: Приказ Минэкономразвития России от 04.06.2015 г. № 346 [Электронный ресурс] // Документ официально опубликован не был. - Сайт Консультант Плюс. - Режим доступа: http://base.consultant.ru/cons/cgi/online.cgi?req=doc;base=LAW;n=181154

35. Об утверждении Порядка работы аттестационной комиссии Министерства экономического развития Российской Федерации: Приказ Минэкономразвития России от 06.06.2013 г. № 305 // Российская газета. - 2013. - № 166

36. об утверждении Положения о порядке проведения аттестации федеральных государственных гражданских служащих, замещающих должности федеральной государственной гражданской службы в центральном аппарате и в загранаппарате Минэкономразвития России, заместителей руководителей федеральных органов исполнительной власти, находящихся в ведении Минэкономразвития России, и руководителей их территориальных органов и порядке сдачи квалификационного экзамена федеральными государственными гражданскими служащими, замещающими должности федеральной государственной гражданской службы в центральном аппарате и в загранаппарате Минэкономразвития России: Приказ Минэкономразвития России 16.10.2012 г. № 679 [Электронный ресурс] // Документ официально опубликован не был. - Сайт Минэкономразвития России. - Режим доступа: http://economy.gov.ru/minec/about/structure/depUD/doc20121217_04

37. С. В. Качушкин Совершенствование института государственной гражданской службы: проблемы теории и практики // Политика и Общество. - 2011. - 6. - С. 11 - 17.

\section{References (transliterated):}

1. Spartak A.N. Napravleniya i metody mezhdunarodnoi konkurentsii v nachale XXI veka: geoekonomicheskie i torgovopoliticheskie aspekty / Rossiiskii vneshneekonomicheskii vestnik. - 2011.-№ 9. - S. 3-15

2. O natsionalizatsii vneshnei torgovli: Dekret SNK RSFSR ot 22.04.1918 g. (dokument utratil silu)// Izvestiya VTsIK. 1918.-№ 80

3. Ivanov A.S. Stranitsy istorii torgovykh predstavitel'stv Rossii za rubezhom / Rossiiskii vneshneekonomicheskii vestnik. 2006.-№ 11. - S. 51-58

4. Likhichev A.E. Vozmozhnosti rossiiskoi ekonomicheskoi diplomatii po zashchite natsional'nykh interesov na mirovom rynke (v ramkakh regional'nykh ob"edinenii i sammitov) / Vneshneekonomicheskii byulleten'.-2005.-№ 5. - S. 36-45 
5. Osnovnye napravleniya deyatel'nosti Pravitel'stva Rossiiskoi Federatsii na period do 2018 goda : utverzhdeny Predsedatelem Pravitel'stva Rossiiskoi Federatsii 14 maya 2015 g. [Elektronnyi dokument] / Dokument ofitsial'no opublikovan ne byl. Sait Pravitel'stva Rossiiskoi Federatsii. - 2015. - Rezhim dostupa: http://government.ru/media/files/QTqv2SI5qYEuu2zOHkOAwguydbKD9Ckf.pdf

6. 0 koordiniruyushchei roli Ministerstva inostrannykh del Rossiiskoi Federatsii v provedenii edinoi vneshnepoliticheskoi linii : Ukaz Prezidenta Rossiiskoi Federatsii ot 8 noyabrya 2011 g. № 1478 // Sobranie zakonodatel'stva Rossiiskoi Federatsii. - 2011.-№ 46 - St. 6477

7. Ob organizatsii i poryadke osushchestvleniya federal'nymi organami ispolnitel'noi vlasti i rossiiskimi gosudarstvennymi uchrezhdeniyami funktsii, svyazannykh s deyatel'nost'yu za rubezhom: Ukaz Prezidenta Rossiiskoi Federatsii ot 14.06.2007 g. № 582 // Sobranie zakonodatel'stva Rossiiskoi Federatsii. - 1997. - St. 2743

8. 0 banke razvitiya : Federal'nyi zakon ot 17.05.2007 g. № 82-FZ // Sobranie zakonodatel'stva Rossiiskoi Federatsii. 2007.-№ 22. - St. 2562

9. Ishchenko E.G., Alekseev P.V. Sovershenstvovanie mekhanizma podderzhki eksporta v Rossii / Den'gi i kredit. - 2015.№ 6. - S. 36-42

10. Ob osnovakh gosudarstvennogo regulirovaniya vneshnetorgovoi deyatel'nosti : Federal'nyi zakon ot 08.12 .2003 g. № 164-FZ // Sobranie zakonodatel'stva Rossiiskoi Federatsii. - 2003.-№ 50. - St. 4850

11. O Ministerstve ekonomicheskogo razvitiya Rossiiskoi Federatsii : Postanovlenie Pravitel'stva Rossiiskoi Federatsii ot 05.06.2008 g. № 437 // Sobranie zakonodatel'stva Rossiiskoi Federatsii. - 2008.-№ 24. - St. 2867

12. Ob obespechenii deyatel'nosti Postoyannogo predstavitel'stva Rossiiskoi Federatsii pri Vsemirnoi torgovoi organizatsii» (vmeste s «Polozheniem o Postoyannom predstavitel'stve Rossiiskoi Federatsii pri Vsemirnoi torgovoi organizatsii») : Postanovlenie Pravitel'stva Rossiiskoi Federatsii ot 31.01.2014 g. № 68 // Sobranie zakonodatel'stva Rossiiskoi Federatsii. - 2014.-№ 6. - St. 584

13. Shlyamin V. Torgpredstvo - effektivnyi instrument ekonomicheskoi diplomatii / Diplomaticheskaya sluzhba. - 2014.№ 1. - S. 18-28

14. Ob optimizatsii sistemy torgovykh predstavitel'stv Rossiiskoi Federatsii v inostrannykh gosudarstvakh: Postanovlenie Pravitel'stva Rossiiskoi Federatsii ot 27.06.2005 g. № 401 // Sobranie zakonodatel'stva Rossiiskoi Federatsii. - 2005.№ 27. - St. 2761

15. O Reestre dolzhnostei Federal'noi gosudarstvennoi grazhdanskoi sluzhby : Ukaz Prezidenta Rossiiskoi Federatsii ot 31.12.2005 g. № 1574 // Sobranie zakonodatel'stve Rossiiskoi Federatsii. - 2006. - № 1. - St. 118

16. Ob utverzhdenii primernykh dolzhnostnykh reglamentov federal'nykh gosudarstvennykh grazhdanskikh sluzhashchikh tsentral'nogo apparata i zagranapparata Minekonomrazvitiya Rossii : Prikaz Minekonomrazvitiya Rossii ot 07.04.2014 g. № 207 // Rossiiskaya gazeta (spetsial'nyi vypusk). - 2014.-№ 128/2

17. Ob utverzhdenii kvalifikatsionnykh trebovanii k professional'nym znaniyam i navykam, neobkhodimym dlya ispolneniya dolzhnostnykh obyazannostei federal'nymi gosudarstvennymi grazhdanskimi sluzhashchimi tsentral'nogo apparata i zagranapparata Ministerstva ekonomicheskogo razvitiya Rossiiskoi Federatsii : Prikaz Minekonomrazvitiya Rossii ot 07.06.2013 g. № 314 // Rossiiskaya gazeta. - 2013.-№ 175

18. 0 primernykh formakh sluzhebnogo kontrakta o prokhozhdenii gosudarstvennoi grazhdanskoi sluzhby Rossiiskoi Federatsii i zameshchenii dolzhnosti gosudarstvennoi grazhdanskoi sluzhby Rossiiskoi Federatsii v Minekonomrazvitiya Rossii: Prikaz Minekonomrazvitiya Rossii ot 03.08.2007 g. № 269 [Elektronnyi resurs]// Dokument ofitsial'no opublikovan ne byl. - Sistema Konsul'tant Plyus. - Rezhim dostupa: http://base.consultant.ru/cons/cgi/online. cgi?req=doc; base $=$ EXP;n=403562

19. Ob utverzhdenii Perechnya dolzhnostei federal'noi gosudarstvennoi grazhdanskoi sluzhby v Ministerstve ekonomicheskogo razvitiya Rossiiskoi Federatsii, pri naznachenii na kotorye grazhdane i pri zameshchenii kotorykh federal'nye gosudarstvennye grazhdanskie sluzhashchie obyazany predstavlyat' svedeniya o svoikh dokhodakh, raskhodakh, ob imushchestve i obyazatel'stvakh imushchestvennogo kharaktera, a takzhe svedeniya o dokhodakh, raskhodakh, ob imushchestve i obyazatel'stvakh imushchestvennogo kharaktera svoikh suprugi (supruga) i nesovershennoletnikh detei : Prikaz Minekonomrazvitiya Rossii ot 05.11.2014 g. № 701 // Rossiiskaya gazeta - 2014.-№ 290

20. Ob utverzhdenii perechnei dolzhnostei, zameshchenie kotorykh vlechet za soboi razmeshchenie svedenii o dokhodakh, raskhodakh, ob imushchestve i obyazatel'stvakh imushchestvennogo kharaktera federal'nykh gosudarstvennykh grazhdanskikh sluzhashchikh Ministerstva ekonomicheskogo razvitiya Rossiiskoi Federatsii i rabotnikov organizatsii, sozdannykh dlya vypolneniya zadach, postavlennykh pered Ministerstvom ekonomicheskogo razvitiya Rossiiskoi Federatsii, a takzhe svedenii o dokhodakh, raskhodakh, ob imushchestve i obyazatel'stvakh imushchestvennogo kharaktera svoikh suprugi (supruga) i nesovershennoletnikh detei na ofitsial'nom saite Ministerstva ekonomicheskogo razvitiya Rossiiskoi Federatsii v informatsionno-telekommunikatsionnoi seti «Internet» : Prikaz Minekonomrazvitiya Rossii ot 07.03.2014 g. № 116 // Rossiiskaya gazeta. - 2014.-№ 160

21. Ob utverzhdenii Instruktsii po formirovaniyu, vedeniyu, khraneniyu, peredache lichnykh del i uchetu personal'nykh dannykh gosudarstvennykh grazhdanskikh sluzhashchikh i rabotnikov Ministerstva ekonomicheskogo razvitiya Rossiiskoi Federatsii : Prikaz Minekonomrazvitiya Rossii ot 02.09.2014 g. № 549 [Elektronnyi resurs] // Dokument ofitsial'no opublikovan ne byl. - Sistema Konsul'tant Plyus. - Rezhim dostupa: http://base.consultant.ru/cons/cgi/online.cgi?req=doc;ba se=LAW;n=168195; dst=0;ts=079F061CCE26E580632A6F3FF165F9C1;rnd=0.3546640919521451

22. Ob utverzhdenii Sluzhebnogo rasporyadka tsentral'nogo apparata Ministerstva ekonomicheskogo razvitiya Rossiiskoi Federatsii, torgovykh predstavitel'stv Rossiiskoi Federatsii v inostrannykh gosudarstvakh: Prikaz Minekonomrazvitiya ot 06.06.2013 g. № 306 // Rossiiskaya gazeta. - 2013.-№ 199 
23. Ob utverzhdenii primernogo sluzhebnogo (trudovogo) rasporyadka torgovogo predstavitel'stva Rossiiskoi Federatsii v inostrannom gosudarstve: Prikaz Minekonomrazvitiya Rossii ot 18 avgusta 2006 g. № 240 [Elektronnyi resurs] // Dokument ofitsial'no opublikovan ne byl. - Sistema Konsul'tant Plyus. - Rezhim dostupa: http://merit.consultant.ru/page. aspx?7783

24. O minimal'noi prodolzhitel'nosti ezhegodnykh dopolnitel'nykh oplachivaemykh otpuskov i ob usloviyakh ikh predostavleniya rabotnikam predstavitel'stv Rossiiskoi Federatsii za granitsei: Postanovlenie Pravitel'stva Rossiiskoi Federatsii ot 21.04.2010 g. № 258 // Sobranie zakonodatel'stva Rossiiskoi Federatsii. - 2010.-№ 17. - St. 2102

25. O prodolzhitel'nosti ezhegodnogo dopolnitel'nogo oplachivaemogo otpuska, predostavlyaemogo rabotnikam, rabotayushchim v stranakh, predusmotrennykh perechnem stran s osobymi (v tom chisle klimaticheskimi) usloviyami, dayushchimi pravo rabotnikam predstavitel'stv Rossiiskoi Federatsii za granitsei na ezhegodnyi dopolnitel'nyi oplachivaemyi otpusk, utverzhdennym postanovleniem Pravitel'stva Rossiiskoi Federatsii ot 21 aprelya 2010 g. N 258 : Prikaz MID Rossii ot 8 avgusta 2011 g. № 14299 // Rossiiskaya gazeta. - 2011.-№ 216

26. Ob utverzhdenii Kodeksa etiki i sluzhebnogo povedeniya gosudarstvennykh grazhdanskikh sluzhashchikh tsentral'nogo apparata i zagranapparata Ministerstva ekonomicheskogo razvitiya Rossiiskoi Federatsii: Prikaz Minekonomrazvitiya Rossii ot 24.06.2011 g. № 292 [Elektronnyi resurs] // Dokument ofitsial'no opublikovan ne byl. - Sistema Konsul'tant Plyus. - Rezhim dostupa: http://merit.consultant.ru/page.aspx?40257

27. Ob organizatsii v Ministerstve ekonomicheskogo razvitiya Rossiiskoi Federatsii raboty po soobshcheniyu Ministrom ekonomicheskogo razvitiya Rossiiskoi Federatsii i federal'nymi gosudarstvennymi grazhdanskimi sluzhashchimi Ministerstva ekonomicheskogo razvitiya Rossiiskoi Federatsii o poluchenii podarka v svyazi s ikh dolzhnostnym polozheniem ili ispolneniem imi dolzhnostnykh obyazannostei, sdache i otsenke podarka, realizatsii (vykupe) i zachislenii sredstv, vyruchennykh ot ego realizatsii : Prikaz Minekonomrazvitiya Rossii ot 15.12 .2014 g. № 803 [Elektronnyi resurs] // Dokument opublikovan ne byl. - Sait Konsul'tant Plyus. - Rezhim dostupa: http://base.consultant.ru/cons/cgi/online. cgi?req=doc; base=LAW;n=176860

28. O denezhnom soderzhanii federal'nykh gosudarstvennykh grazhdanskikh sluzhashchikh, zameshchayushchikh dolzhnosti federal'noi gosudarstvennoi grazhdanskoi sluzhby v federal'nom gosudarstvennom organe, nakhodyashchemsya za predelami territorii Rossiiskoi Federatsii: Ukaz Prezidenta Rossiiskoi Federatsii ot 25.07.2006 g. № 764 // Sobranie zakonodatel'stva Rossiiskoi Federatsii. - 2006.-№ 31 (ch.1). - St. 3460

29. O povyshenii okladov mesyachnogo denezhnogo soderzhaniya/dolzhnostnykh okladov sotrudnikov zagranapparata Minekonomrazvitiya Rossii: Prikaz Minekonomrazvitiya Rossii ot 30.11.2007 g. № 420 [Elektronnyi resurs] // Dokument ofitsial'no opublikovan ne byl. - Sait Konsul'tant Plyus. - Rezhim dostupa:

30. O razmerakh i poryadke vyplaty ezhemesyachnykh nadbavok k dolzhnostnomu okladu v rublyakh za osobye usloviya grazhdanskoi sluzhby federal'nym gosudarstvennym grazhdanskim sluzhashchim zagranapparata Minekonomrazvitiya Rossii: Prikaz Minekonomrazvitiya Rossii ot 09.04.2007 g. № 121 // Rossiiskaya gazeta. - 2007.-№ 98

31. Ob utverzhdenii Polozheniya o razmerakh, usloviyakh i poryadke vyplaty ezhemesyachnoi nadbavki k mesyachnomu dolzhnostnomu okladu v inostrannoi valyute za osobye usloviya raboty v strane prebyvaniya rabotnikam zagranapparata Minekonomrazvitiya Rossii: Prikaz Minekonomrazvitiya Rossii ot 28.07.2009 g. № 296 // Rossiiskaya gazeta. - 2009.№ 194

32. O poryadke i usloviyakh vyplaty ezhemesyachnykh protsentnykh nadbavok k dolzhnostnomu okladu (tarifnoi stavke) rabotnikam tsentral'nogo apparata i zagranapparata Ministerstva ekonomicheskogo razvitiya Rossiiskoi Federatsii, podvedomstvennykh organizatsii, dopushchennym k gosudarstvennoi taine na postoyannoi osnove, i sotrudnikam strukturnykh podrazdelenii po zashchite gosudarstvennoi tainy: Prikaz Minekonomrazvitiya Rossii ot 30.12 .2007 g. № 467 // Rossiiskaya gazeta. - 2008.-№ 39

33. Ob utverzhdenii Polozheniya o premirovanii i vyplate material'noi pomoshchi rabotnikam zagranapparata Ministerstva ekonomicheskogo razvitiya Rossiiskoi Federatsii: Prikaz Minekonomrazvitiya Rossii ot 25.08.2009 g. № 343 // Rossiiskaya gazeta. - 2009.-№ 194

34. Ob organizatsii raboty po uvedomleniyu federal'nymi gosudarstvennymi grazhdanskimi sluzhashchimi Minekonomrazvitiya Rossii predstavitelya nanimatelya o namerenii vypolnyat' inuyu oplachivaemuyu rabotu (o vypolnenii inoi oplachivaemoi raboty) i po registratsii etikh uvedomlenii: Prikaz Minekonomrazvitiya Rossii ot 04.06.2015 g. № 346 [Elektronnyi resurs] // Dokument ofitsial'no opublikovan ne byl. - Sait Konsul'tant Plyus. - Rezhim dostupa: http://base. consultant.ru/cons/cgi/online.cgi?req=doc; base=LAW;n=181154

35. Ob utverzhdenii Poryadka raboty attestatsionnoi komissii Ministerstva ekonomicheskogo razvitiya Rossiiskoi Federatsii: Prikaz Minekonomrazvitiya Rossii ot 06.06.2013 g. № 305 // Rossiiskaya gazeta. - 2013. - № 166

36. Ob utverzhdenii Polozheniya o poryadke provedeniya attestatsii federal'nykh gosudarstvennykh grazhdanskikh sluzhashchikh, zameshchayushchikh dolzhnosti federal'noi gosudarstvennoi grazhdanskoi sluzhby v tsentral'nom apparate i v zagranapparate Minekonomrazvitiya Rossii, zamestitelei rukovoditelei federal'nykh organov ispolnitel'noi vlasti, nakhodyashchikhsya v vedenii Minekonomrazvitiya Rossii, i rukovoditelei ikh territorial'nykh organov i poryadke sdachi kvalifikatsionnogo ekzamena federal'nymi gosudarstvennymi grazhdanskimi sluzhashchimi, zameshchayushchimi dolzhnosti federal'noi gosudarstvennoi grazhdanskoi sluzhby v tsentral'nom apparate i v zagranapparate Minekonomrazvitiya Rossii: Prikaz Minekonomrazvitiya Rossii 16.10.2012 g. № 679 [Elektronnyi resurs] // Dokument ofitsial'no opublikovan ne byl. - Sait Minekonomrazvitiya Rossii. - Rezhim dostupa: http://economy.gov.ru/minec/about/structure/ depUD/doc20121217_04

37. S. V. Kachushkin Sovershenstvovanie instituta gosudarstvennoi grazhdanskoi sluzhby: problemy teorii i praktiki // Politika i Obshchestvo. - 2011. - 6. - C. $11-17$. 